Annals of Warsaw University of Life Sciences - SGGW

Land Reclamation No 48 (4), 2016: 289-297

(Ann. Warsaw Univ. Life Sci. - SGGW, Land Reclam. 48 (4), 2016)

\title{
Selected biometric and mechanical properties of the common reed Phragmites australis and the reed sweet grass Glyceria maxima rhizomes
}

\author{
WERONIKA KOWALIK, KINGA PACHUTA, JERZY JEZNACH \\ Department of Environmental Improvement, Warsaw University of Life Sciences - SGGW
}

\begin{abstract}
Selected biometric and mechanical properties of the common reed Phragmites australis and the reed sweet grass Glyceria maxima rhizomes. The results on the selected biometric and mechanical properties of common reed Phragmites australis and reed sweet grass Glyceria maxima were presented. The experiments were conducted with the help of the universal testing machine Instron 5966. The underground biomasses, diameters, tensile forces, displacements and tensile strengths for summer and winter rhizomes of both species were assessed and compared. The final results indicate that rhizomes of common reed had higher values of the studied parameters of biometric and stretching than sweet reed grass rhizomes. Therefore, there are more opportunities to use them to protect the coastline.
\end{abstract}

Key words: stem density, rhizomes' fresh biomass, tensile forces, displacement, tensile strength

\section{INTRODUCTION}

The roots of trees, bushes, herbaceous plants and grass turfs stabilize substrate. They prevent slopes and shorelines against erosion (Rokita 1970, Schiechtl 1980, Nilaweera and Nutalaya 1999, Dąbkowski et al. 2004, Bischetti 2005, Schutten et al. 2005, De Baets et al. 2008, Abdi et al. 2010, Baryła and Hejduk 2010, Miller et al. 2014). There was a lack of informa- tion about the strengthening properties of helophytes' rhizomes. De Baets et al. (2008) were the only ones to analyze the tensile strength of two species of such plants (Phragmites australis and Juncus acutus) collected in the region of the Mediterranean Sea.

The aim of the studies is to obtain and compare data regarding selected biometric and mechanical properties of rhizomes of two common species of helophytes: common reed Phragmites australis and reed sweet grass Glyceria maxima. Both species create the largest plant communities in Poland (Podbielkowski and Tomaszewicz 1996). They act as an anti pollution filter (Obarska-Pempkowiak et al. 2010, Koda 2013). They constitute valuable ecosystems that provide habitats for plants and animals listed in the Directives of the Natura 2000 and The Red List of Threatened Species.

\section{MATERIAL AND METHODS}

The rhizomes of reed sweet grass and common reed were collected from the fully mature communities of Lake Urszulewskie $\left(52^{\circ} 57^{\prime} 40^{\prime \prime} \mathrm{N}, 19^{\circ} 34^{\prime} 58^{\prime \prime} \mathrm{E}\right)$. This 
is a eutrophic lake, located in the temperate zone, in the Chełmińsko-Dobrzyński Lake District near the city of Sierpc.

The whole plant samples were collected by hand in February and in July. The selection was carried out on location, with excluding rhizomes which exhibited mechanical damages, deformations and the disease-indicators. The chosen specimens were then transported to the laboratories of the Water Center of the Warsaw University of Life Sciences - SGGW in Warsaw. The storage time of the plant material did not exceed $24 \mathrm{~h}$.

The following biometric parameters: stem density, rhizomes' diameter and fresh underground biomass per $\mathrm{m}^{2}$ up to $0.1 \mathrm{~m}$ deep were assessed. The tensile forces and the displacements of the rhizomes were assessed with using an Instron 5966 universal testing machine (2009), with a measurement range of strength values up to $10 \mathrm{kN}$. The rhizomes were placed in metal clamps of the Instron machine as pictured in Figure 1. In order to prevent the delicate plant material from damage in the area of the clamps, a tape reinforced with glass fibers was used.

The tensile strength was calculated from the following equation:

$$
\operatorname{Tr}=F \cdot A^{-1}(\mathrm{~Pa})
$$

where:

$F$ - maximum force needed to break the rhizome, tensile force $(\mathrm{N})$;

$A$ - cross-sectional area of rhizome at the point of rupture $\left(\mathrm{m}^{2}\right)$.

Twenty important results were obtained for summer rhizomes of common reed and ten for their winter counterparts. Sixteen and fifteen important results were obtained for summer and winter rhizomes of reed sweet grass, respectively.

Microsoft Excel 2002 and Statistica 10 were used to carry out the statistical analysis of results. The trend line, equations describing the trend line, and the value of $R^{2}$ (determination coefficient) were determined. The standard

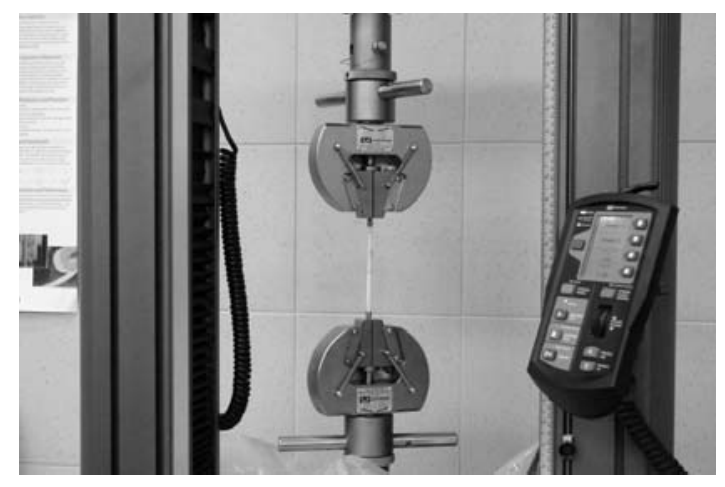

FIGURE 1. The depiction of the rhizomes - placing in the clamps of the Instron 5966 tensile strength measuring machine 
deviations were calculated. Two-way analysis of variance (Anova) was performed in order to assess whether there were significant differences between the summer and winter rhizomes of common reed and reed sweet grass. When the differences between the variables were significant $(p<0.05)$, post-hoc: RIR Tukey's test was additionally carried out. The level of significance was accepted as $\alpha=0.05$. One-way analysis of variance was performed in order to assess the differences between the rhizomes of common reed from the temperate and the Mediterranean zones.

\section{RESULTS}

\section{Biometric parameters}

The first spring aboveground stems appeared at the end of February. The highest stem density was about 110 stems per $\mathrm{m}^{2}$ for common reed and 130 stems per $\mathrm{m}^{2}$ for reed sweet grass in July and August. The new aboveground stems grew also during autumn-winter period. They grew sparsely and overwinter under snow cover. The underground biomass does not show the significant seasonal changes (Table 1).

TABLE 1. The fresh biomass and the diameter of the studied rhizomes

\begin{tabular}{|l|l|c|c|}
\hline $\begin{array}{l}\text { Plant } \\
\text { species }\end{array}$ & Season & $\begin{array}{c}\text { Fresh bio- } \\
\text { mass range } \\
\left(\mathrm{kg} \cdot \mathrm{m}^{-2}\right)\end{array}$ & $\begin{array}{c}\text { Rhizomes' } \\
\text { diameter } \\
(\mathrm{mm})\end{array}$ \\
\hline $\begin{array}{l}\text { Common } \\
\text { reed }\end{array}$ & summer & $3.3-9.0$ & $5.9-11.5$ \\
\cline { 2 - 4 } $\begin{array}{l}\text { Reed } \\
\text { sweet } \\
\text { grass }\end{array}$ & sumter & $1.5-10.1$ & $4.3-8.7$ \\
\cline { 2 - 4 } & winter & $0.9-3.8$ & $4.0-8.2$ \\
\hline
\end{tabular}

\section{Tensile forces and displacement}

The values of tensile forces for common reed and reed sweet grass rhizomes increased along with the cross-sectional area of the samples (Fig. 2). The average tensile forces and their standard deviations, the significance of differences between average tensile forces for summer and winter rhizomes of both studied plant species were presented in Table 2.

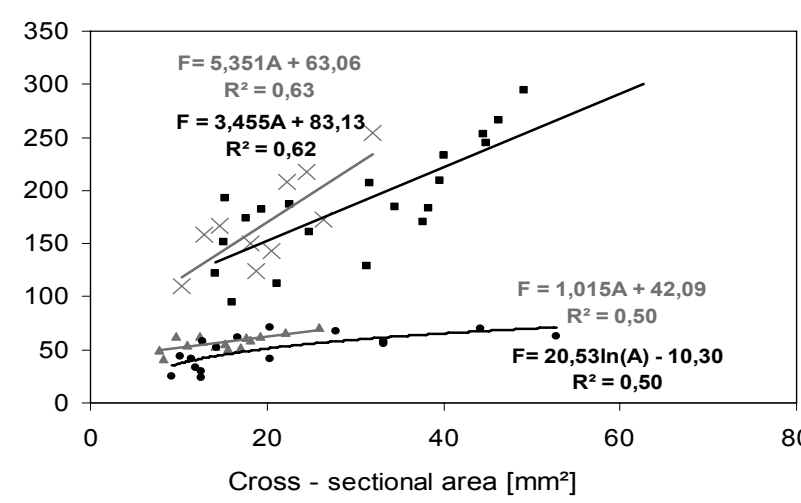

winter rhizome of
common reed
- summer rhizome of
common reed
winter rhizome of
reed sweet grass
- summer rhizome of
reed sweet grass
(Kowalik 2013,
Kowalik 2014)

FIGURE 2. The relationship between the tensile force and the cross-sectional area of rhizomes 
TABLE 2. Tensile forces and their standard deviations $(S D)$, significance of differences between average tensile forces for rhizomes

\begin{tabular}{|l|c|c|c|c|c|c|c|}
\hline \multirow{2}{*}{ Plant species } & \multirow{2}{*}{ Season } & \multicolumn{4}{|c|}{$p$ value } & \multirow{2}{*}{$\begin{array}{c}\text { Tensile forces } \\
(\mathrm{N})\end{array}$} & \multirow{2}{*}{$S D(\mathrm{~N})$} \\
\cline { 3 - 8 } & & 1 & 2 & 3 & 4 & \\
\hline \multirow{2}{*}{$\begin{array}{l}\text { Reed sweet } \\
\text { grass }\end{array}$} & summer (1) & - & 0.929 & 0.000 & 0.000 & $25.0-70.0$ & 15.8 \\
\cline { 2 - 8 } & winter (2) & 0.929 & - & 0.000 & 0.000 & $42.0-70.0$ & 7.3 \\
\hline \multirow{2}{*}{ Common reed } & summer (3) & 0.000 & 0.000 & - & 0.609 & $95.0-295.0$ & 52.6 \\
\cline { 2 - 8 } & winter (4) & 0.000 & 0.000 & 0.609 & - & $110.0-254.0$ & 44.2 \\
\hline
\end{tabular}

For summer rhizomes of common reed, the displacement range was 6.5$-37.0 \mathrm{~mm}$, whereas for winter rhizomes it ranged from 6.5 to $50.0 \mathrm{~mm}$. The respective values for reed sweet grass were 9-44 and 9-28 mm (Table 3).

TABLE 3. Average displacement for rhizomes

\begin{tabular}{|l|l|c|}
\hline $\begin{array}{l}\text { Plant } \\
\text { species }\end{array}$ & Parts of plants & $\begin{array}{c}\text { Average } \\
\text { displacement } \\
(\mathrm{mm})\end{array}$ \\
\hline $\begin{array}{l}\text { Common } \\
\text { reed }\end{array}$ & summer rhizome & 20.4 \\
\cline { 2 - 3 } & winter rhizome & 14.5 \\
\hline $\begin{array}{l}\text { Reed sweet } \\
\text { grass }\end{array}$ & summer rhizome & 21.4 \\
\cline { 2 - 3 } & winter rhizome & 17.5 \\
\hline
\end{tabular}

\section{Tensile strength}

The values of tensile strength for common reed and reed sweet grass rhizomes decreased when the cross-sectional areas of the samples increase (Fig. 3). The average tensile strengths and their standard deviations, the significance of differences between average tensile strengths for summer and winter rhizomes of both studied plant species were presented in Table 4.

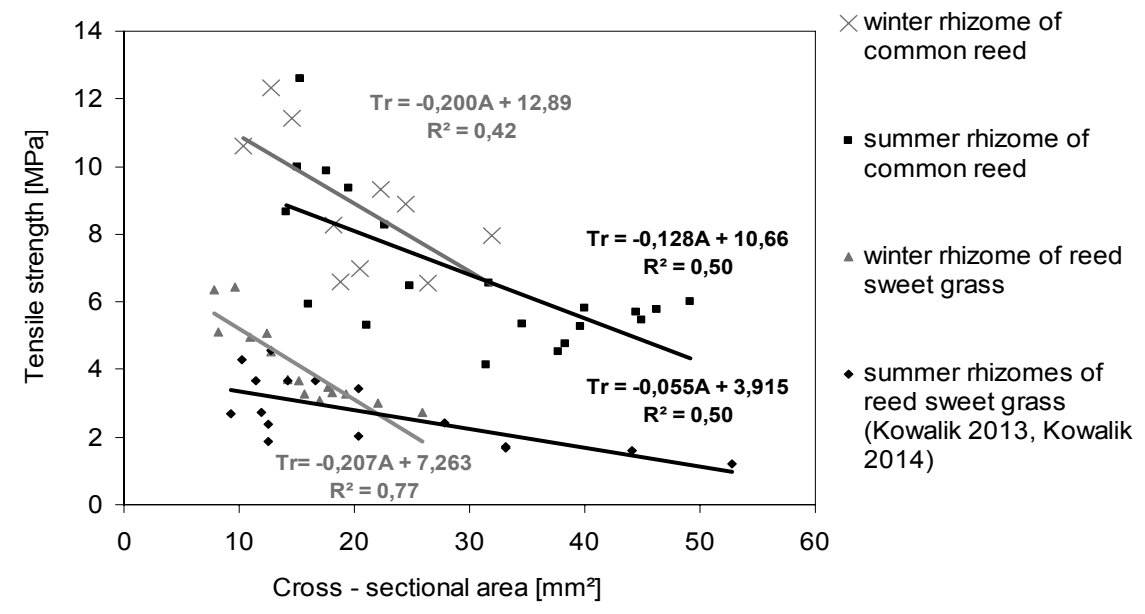

FIGURE 3. The relationship between the tensile strength and cross-sectional area of rhizomes 
TABLE 4. Tensile strengths and their standard deviations (SD), significance of differences between average tensile strengths for rhizomes

\begin{tabular}{|c|c|c|c|c|c|c|c|}
\hline \multirow{2}{*}{ Plant species } & \multirow{2}{*}{ Season } & \multicolumn{4}{|c|}{$p$ Value } & \multirow{2}{*}{$\begin{array}{l}\text { Tensile forces } \\
\qquad(\mathrm{MPa})\end{array}$} & \multirow{2}{*}{$\begin{array}{c}S D \\
(\mathrm{MPa})\end{array}$} \\
\hline & & 1 & 2 & 3 & 4 & & \\
\hline \multirow{2}{*}{$\begin{array}{l}\text { Reed sweet } \\
\text { grass }\end{array}$} & summer (1) & - & 0.117 & 0.000 & 0.000 & $1.2-4.5$ & 1.04 \\
\hline & winter (2) & 0.117 & - & 0.000 & 0.000 & $2.7-6.4$ & 1.20 \\
\hline \multirow{2}{*}{ Common reed } & summer (3) & 0.000 & 0.000 & - & 0.013 & $4.1-12.6$ & 2.24 \\
\hline & winter (4) & 0.000 & 0.000 & 0.013 & - & $6.6-12.3$ & 2.03 \\
\hline
\end{tabular}

\section{DISCUSSION}

The fresh biomass values for summer and winter rhizomes of common reed were three times higher than the values of this parameter for summer and winter rhizomes of reed sweet grass (Table 1). As many as four main rhizomes grew out from a single above-ground stem, reaching lengths of up to $10 \mathrm{~m}$ and diameters of up to $10 \mathrm{~mm}$. Numerous peripheral rhizomes extended out from main rhizomes in various directions. Meanwhile, three or four rhizomes grew out from a single above-ground stem of reed sweet grass, reaching lengths of up to $0.5 \mathrm{~m}$ and diameters of up to $8 \mathrm{~mm}$. Lower values of underground biomasses' and rhizomes' diameters of both species (Table 1) in winter were caused by some dying rhizomes and roots.

The tensile forces values for summer and winter rhizomes of common reed were 3-4 times higher than the values for summer and winter rhizomes of reed sweet grass (Fig. 1, Table 2). The surrounding environment, apart from the cross-sectional area, may also have had influence on the tensile forces. Common reed grew not only in the littoral zone of lake and, but also in places where the water is $2-4 \mathrm{~m}$ deep, bordering the pelagial zone. Reed sweet grass, on the other hand, preferred quiet areas, with water depth not exceeding $0.3 \mathrm{~m}$. It often grew under the protective cover of other bulrush communities. It was possible that the rhizomes of common reed had to withstand greater stress connected with tensile forces resulting from the weight of the ground and water, as well as the movements of water.

The winter rhizomes had lower values of displacement than the summer ones, probably because of lignification and shrinkage of tissues under the influence of low temperatures (Table 3).

The tensile strength values for summer and winter rhizomes of common reed were 1.3-3 times higher than the values for summer and winter rhizomes of reed sweet grass (Fig. 3, Table 4). The tensile strength was a parameter which is dependent on the tensile force and the cross-sectional area.

The values of tensile strength of reed rhizomes growing in the temperate zone, presented in the present work, could be compared to data obtained by De Baets (2008), who had determined 
the tensile strength of common reed rhizomes growing in the Mediterranean zone.

The values of tensile strength of reed rhizomes growing in the temperate zone, presented in the present work, could be compared to data obtained by De Baets (2008), who had determined the tensile strength of common reed rhizomes growing in the Mediterranean zone.

In summer rhizomes of common reed found in the temperate zone, the relationship between tensile strength and the cross-sectional area was expressed by linear equation (Fig. 3 ) and then by polynomial equation $\operatorname{Tr}=35.128 \cdot A^{-0.51}$ at $R^{2}=0.53$ (Fig. 4). De Baets' (2008) results, on the other hand, were expressed by the polynomial equation $T r=31.20$. $\cdot \mathrm{A}^{-0.39}$ at $R^{2}=0.92$ (Fig. 4). and 34.29 respectively) and "b" $(-0.51$ and -0.78 ) constants were similar. The differences in the equations and tensile strength values were the result of applying a different type of tensile strength testing machine. More biometric and tensile tests on common reed from different waters of temperate zone should have been carried in order to obtain more representative results of the research.

The tensile strength of tree roots was at least two times higher than that of common reed and reed sweet grass rhizomes (Table 5). However, European beech Fagus silvatica roots were sensitive to changes in the water level and excessive amounts of water in the soil (Rokita 1970). European ash Fraxinus excelsior was often found growing along streams and rivers, but did not

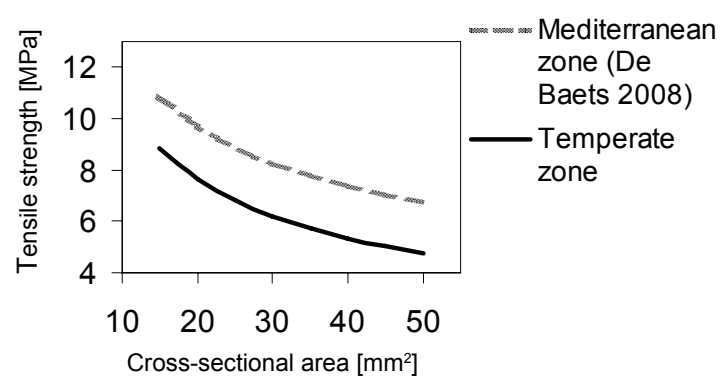

\begin{tabular}{|l|c|c|}
\hline \multirow{2}{*}{ Climate zone } & \multicolumn{2}{|c|}{$p$ Value } \\
\cline { 2 - 3 } & 1 & 2 \\
\hline Mediterranean (1) & - & 0.01 \\
\hline Temperate (2) & 0.01 & - \\
\hline
\end{tabular}

FIGURE 4. The comparison of relationships between tensile strengthes and cross-sectional areas. The significance of differences between average tensile strengthes for common reed's rhizomes from Mediterranean and temperate zone

The statistical analysis showed that the differences between tensile strength values for rhizomes from Mediterranean and temperate zone were significant (Fig. 4). When comparing the two exponential equations to each other, it could be observed that the "a" $(35.128$ tolerate shortages of oxygen, water that was stagnant for long periods of time and changes in the water level. Norway spruce Picea abies preferred dry and sandy soils. English oak Quercus robur could withstand flooding lasting up to approximately three months. This was 
TABLE 5. Average tensile strength of roots and rhizomes of selected plant species

\begin{tabular}{|l|l|}
\hline \multicolumn{1}{|c|}{ Plant species } & \multicolumn{1}{|c|}{$\begin{array}{c}\text { Average tensile strength according to various authors } \\
\text { (MPa) }\end{array}$} \\
\hline \multicolumn{2}{|c|}{ Terrestrial trees and shrubs } \\
\hline European beech Fagus silvatica & 22.2 (Rokita 1970); 57.5 (Bischetti 2005) \\
\hline European ash Fraxinus excelsior & 18.9 (Rokita); 26.0 (Riedl 1937) \\
\hline Norway spruce Picea abies & 17.6 (Rokita 1970); 28.0 (Schiechtl 1980); 38.9 (Bischetti 2005) \\
\hline English oak Quercus robur & 32.0 (Schiechtl 1980) \\
\hline Crack willow Salix fragilis & 18.0 (Schiechtl 1980) \\
\hline \multicolumn{2}{|c|}{ Marshland plants } \\
\hline Common reed Phragmites australis & 6.8 (Kowalik 2015) \\
\hline Reed sweet grass Glyceria maxima & 2.7 (Kowalik et al. 2013, Kowalik et al. 2014, Kowalik 2015) \\
\hline
\end{tabular}

too short period of time for its roots to be suitable for permament shoreline protection (Seneta and Dolatowski 2008).

Due to their expansibility, common reed rhizomes were suitable for places where the intense overgrowing was desirable. In other cases, common reed's overgrowing could be reduced with the help of water depth of over $5 \mathrm{~m}$. Common reed could be used in small and shallow ponds or lakes in the case of:

a) severely eutrophized water, or water that was salty or contaminated with municipal waste, in other words where applying other species of bulrush was not possible;

b) a readiness to carry costs connected with the annual conservation of the waterbody, and the possibility of utilizing the removed biomass, e.g. for agricultural or heating purposes;

c) the need for a ground reinforcing element with a deep rhizome system.

Reed sweet grass on the other hand, could be applied even in small ponds and waterholes, as it was not as expansive as common reed.
There was a phenomenon called the reed die-back in the lakes of Europe and Mediterranean zone. This phenomenon was described by various researchers (Ostendorp 1989, van der Putten 1997, Brix 1999). Therefore, artificial introduction of common reed on the shorelines might be an instrument to prevent the reeds from extinction in lakes affected by this phenomenon.

\section{CONCLUSIONS}

1. The values of average fresh biomass for summer and winter rhizomes of common reed were approximately 5.6 and $4.9 \mathrm{~kg} \cdot \mathrm{m}^{-2}$, respectively. The average values of this parameter for summer and winter rhizomes of reed sweet grass were 1.8 and $1.6 \mathrm{~kg} \cdot \mathrm{m}^{-2}$, respectively.

2. The values of average tensile forces for summer and winter rhizomes of common reed were approximately 187.5 and $170.3 \mathrm{~N}$, respectively. Reed sweet grass showed 3-4 times lower values: 49.6 and $57.5 \mathrm{~N}$. 
3. The average tensile strength values for summer and winter rhizomes of common reed were 6.8 and $8.88 \mathrm{MPa}$. The average values of this parameter for summer and winter rhizomes of reed sweet grass were 2.7 and $4.1 \mathrm{MPa}$, respectively.

4. Common reed from the Mediterranean zone had slightly (about 1.2 times) higher tensile strength values. This might be the result of both milder winters of the Mediterranean zone and more demanding habitat. This raises suspicions that tensile strength tests on the rhizomes of common reed collected from stagnant and flowing water would solve this problem.

5. Common reed had higher values of the studied biometric and tensile parameters than reed sweet grass. Therefore, there were wider possibilities (greater opportunities) to use it in shoreline protection.

\section{REFERENCES}

ABDI E., MAJNOUNIAN B., RAHIMI H., ZOBEIRI M. 2009: Distribution and tensile strength of Hornbeam (Carpinus betulus) roots growing on slopes of Caspian Forests. Iran. J. For. Res. 20 (2), 105-110.

BARYŁA A., HEJDUK L. 2010: The effect of plant cover on the mechanical composition of eroded soil. Ann. Warsaw Univ. Life Sci. - SGGW, Land Reclam. 42 (2), 241-247.

BISCHETTI G.B., CHIARADIA E., SIMONATO T., SPEZIALI B. 2005: Root strength and root area ratio of forest species in Lombardy (Northern Italy). Plant and Soil 278, 11-22.

BRIX H. 1999: The European research project on reed die-back and progression (EUREED).
Limnologica - Ecology and Management of Inland Waters 29 (1), 5-10.

DĄBKOWSKI Sz.L., PACHUTA K. 1996: Vegetation and hydraulics of overgrown channels. IMUZ, Falenty [in Polish].

De BAETS S., POESEN J., REUBENS B., WEMANS K., De BAERDEMAEKER J., MUYS B. 2008: Root tensile strength and root distribution of typical Mediterranean plant species and their contribution to soil shear strength. Plant Soil 305, 207-226.

Instron. 5960 Series Dual Column Frames System Support. Illinois Tools Works Inc., 2009.

KODA E., PACHUTA K., OSIŃSKI P. 2013: Potential of plants application in the initial stage of landfill reclamation process. Pol. J. Environ. Stud. 22 (6), 1731-1739.

KOWALIK W., PACHUTA K., JEZNACH J. 2013: The stabilization and protection of shorelines using the broadleaf cattail and reed sweet grass. Ann. Warsaw Univ. Life Sci. - SGGW, Land Reclam. 45 (1), 61-70.

KOWALIK W., PACHUTAK., JEZNACH J. 2014: Reed sweet grass - role in shoreline protection. Pol. J. Environ. Stud. 23, 4, 1335-1340.

KOWALIK W. 2015. The studies on biometric and tensile parameters of shorelines-reinforcing helophytes. Warsaw University of Life Sciences, doctorial thesis [unpublished].

MILLER O., ALBAYRAK I., NIKORA V., O'HARE M. 2012: Biomechanical properties of aquatic plants and their effects on plant-flow interactions in streams and rivers. Aquat. Sci. 74, 31-44.

NILAWEERA N.S., NUTALAYA P. 1999: Role of tree roots in slope stabilisation. Bull. Eng. Geol. Env. 57 (4), 337-342.

OBARSKA-PEMPKOWIAK H., GAJEWSKAM., WOJCIECHOWSKA E. 2010: Hydrophic treatment of water and sewage. PWN, Warszawa [in Polish].

OSTENDORP W. 2012: Die-back of reeds in Europe - a critical review of literature. Aquat. Bot. 35 (1), 5-26.

PODBIELKOWSKI Z., TOMASZEWICZ H. 1996: An outline of hydrobotanics. PWN, Warszawa [in Polish].

RIEDL H. 1937: Bau und leistungen des wurzelholzes. Jahrb. Wiss. Bot. 85, 1-75. 
ROKITA Z. 1970: Root systems of selected trees and shrubs and their suitability for the biological encasement of mountain streams. Ochrona przyrody 35, 100-155 [in Polish].

SCHUTTEN J., DAINTY J., DAVY A.J. 2005: Root anchorage and its significance for submerged plants in shallow lakes. J. Ecol. 93 (3), 556-571.

SENETA W., DOLATOWSKI J. 2008: Dendrology. PWN, Warszawa [in Polish].

SCHIECHTL H.M. 1980: Bioengineering for land reclamation and conservation. University of Alberta Press, Alberta.

Van der PUTTEN W.H. 1997: Die-back of Phragmites australis in European wetlands: an overview of the European research programme on reed die-back and progression (1993-1994). Aquat. Bot. 59 (3-4), 263-275.

Streszczenie: Wybrane właściwości biometryczne i mechaniczne ktaczy trzciny pospolitej Phragmites australis i manny mielec Glyceria maxima. W artykule przedstawiono wyniki badań nad wybranymi właściwościami biometrycznymi i mechanicznymi kłączy trzciny pospolitej i manny mielec. Doświadczenia przeprowadzono za po- mocą uniwersalnej maszyny testującej Instron 5966. Określono wielkości biomasy, średnic, sił zrywających, przemieszczenia i wytrzymałości na zerwanie kłączy letnich i zimowych obu gatunków. Uzyskane wartości wytrzymałości na zerwanie porównano z danymi innych badań dla wybranych gatunków krzewów i drzew. Większe wartości badanych parametrów biometrycznych i wytrzymałościowych stwierdzono u kłączy trzciny pospolitej, w związku z tym są szersze możliwości jej wykorzystania w umacnianiu brzegów zbiorników wodnych.

\section{MS received July 2016}

\section{Authors' address:}

Weronika Kowalik, Kinga Pachuta, Jerzy Jeznach Katedra Kształtowania Środowiska Wydział Budownictwa i Inżynierii Środowiska SGGW

ul. Nowoursynowska 159, 02-776 Warszawa

Poland

e-mail: weronika85sier@interia.pl 